\title{
Fiturebot: CS Chatbot Application using Nazief-Adriani Algorithm
}

\author{
Anthony Nugraha ${ }^{1}$, Seng Hansun ${ }^{2}$ \\ ${ }^{1}$ Informatics Department, Universitas Multimedia Nusantara, Indonesia, anthony.nugraha@student.umn.ac.id \\ ${ }^{2}$ Informatics Department, Universitas Multimedia Nusantara, Indonesia, hansun@umn.ac.id
}

\begin{abstract}
A company engaged in information technology, namely PT Fiture Teknologi Inovasi, has problems related to information. The absence of a system that can answer user questions automatically on the company's website, as well as the number of repetitive questions raises problems with the exchange of information between the company and the customer. One solution that can be done in overcoming this problem is by building and implementing chatbot applications as customer service. A Chatbot is an application based on artificial intelligence (AI) that can interact with customers automatically. The chatbot customer service application, Fiturebot, will be built using the AIML method as the knowledge base from the chatbot. The text preprocessing process will be implemented on the chatbot, and the Nazief-Adriani algorithm will be used as the stemming method to extract the basic word from the sentences that the customer has submitted. The application was successfully designed and built and has been tested using the Technology Acceptance Model (TAM) method by generating a number of $83.44 \%$ of respondents who agree that the application does not require much effort to use it, and $84.78 \%$ of respondents agree that the application can improve user performance in finding the information that they needed.
\end{abstract}

Key words: Customer Service, Chatbot, Text Preprocessing, Artificial Intelligence Markup Language (AIML), Nazief-Adriani Algorithm.

\section{INTRODUCTION}

The technology applied to process, obtain, compile, store, and manipulate data in various ways that results to a quality, relevant, accurate, and timely information is known as Information Technology. It can be used in both personal, business, and government settings and used a set of computers to process data, a network system to connect, and telecommunications technology for data spreading and sharing globally [1].

The development of information technology has created various innovations. One innovation that has developed through this development is a chatbot. Chatbot or chatter robot is a self-explain system that uses super-advanced technology mechanisms that are accessed through chat interfaces. A chatbot is a smart machine-based program that helps in having conversations with native humans [2].

In designing chatbots, it takes stages of word processing so that the program can understand the message conveyed by the customer, namely the stage of text preprocessing. Text preprocessing is divided into separate stages, including tokenizing, folding cases, filtering, and stemming. One of the stemming algorithms that can be used in designing customer service chatbot is the Nazief and Adriani algorithm [3].

The chatbot evaluation will be conducted using the Technology Acceptance Model (TAM), a system evaluation model to determine whether a user accepts and wants to use new technology or not [4].

\section{BASIC CONCEPTS}

\subsection{Customer Service}

In general, customer service is an activity that is intended or addressed for someone to provide satisfaction to customers through the services provided by someone. This means that each customer service must serve all customer needs satisfactorily. Therefore, customer service should be smart in finding solutions for any problem faced by customers [5].

\subsection{Chatbot and Text Preprocessing}

A chatbot can be considered as a question and answer system where the admin will provide information and knowledge to users. It is a software designed and built to simulate conversations with human partners [6].

Text Preprocessing is the initial stage of text mining that aims to prepare text into data that will be processed in the next stage. In text mining, raw data that contains information has an arbitrary structure, so it needs the process of converting the form into structured data as needed, which is usually numerical values. This process is called Text Preprocessing. The stages of Text Preprocessing are divided into several phases, i.e., case folding, filtering, tokenizing, and stemming [3]. 


\subsection{Nazief-Adriani Algorithm}

The algorithm made by Nazief and Adriani has the following stages [7], [8]:

1. Words from the filtering process will be taken and processed. If the root word has been found, then the word is the root word. If the word already exists in the database, the algorithm stops. If it is not in the database, the algorithm will continue to the next stage.

2. Inflection Suffixes ("-lah", "-kah", "-ku", "-mu", or "-nya") are discarded. If it is in the form of particles ("-lah", "-kah", "-tah" or "-pun") then this step is repeated again to delete obsessive pronouns ("-ku", "-mu", or "-nya"), If there is such one.

3. Delete Derivation Suffixes ("-i", "-an" or "-kan"). If the word is found in the dictionary, the algorithm stops. If not then go to step $3 \mathrm{a}$

a. If "-an" has been deleted and the last letter of the word is "-k," then "-k" is also deleted. If the word is found in the database, the algorithm stops. If not found, then do step $3 b$.

b. Deleted suffixes ("-i", "-an" or "-kan") are returned, go to step 4.

4. Remove Derivation Prefix. If in step 3, there is a suffix that is deleted then proceed to step $4 \mathrm{a}$, if not continue to step $4 b$.

a. Check the prefix-suffix combination table that is not allowed. If it is found, the algorithm stops, if it does not go to step $4 \mathrm{~b}$.

b. For $i=1$ to 3 , specify the type of prefix then delete the prefix. If the root word has not been found, do step 5 , if the word has been found, stop the algorithm. Note: if the second prefix equals the first prefix, stop the algorithm.

5. Do the Recoding.

6. If all steps have been completed, but the process is still unsuccessful, then the initial word is the root word. Process terminated.

\subsection{AIML and TAM}

Artificial Intelligence Markup Language or AIML allows users to enter data into chatbots [9]. AIML was created by Richard S. Wallace and Alicebot community from 1995 to 2000 [10]. At first, AIML was adapted based on non-XML grammar, which later became the basis for the first Alicebot, Artificial Linguistic Internet Entity Computer (A.L.I.C.E). It contains a class of data objects known as the AIML objects and explains the behavior of computer programs that process them. AIML objects consist of units known as topics and categories, that have described data or not described data. The data parsed consists of character data and AIML elements. The AIML element summarizes the stimulus-response knowledge resided in a document. The character data could be parsed by AIML translators or left unprocessed [10].

In 1989, Davis introduced the Technology Acceptance Model or TAM as a model for adopting information system users. TAM's purpose is to establish a foundation for determining the external factors' influence towards the beliefs, attitudes, and goals of computer users [11].

\section{RESEARCH METHOD}

\subsection{Methodology}

The methods carried out in the study are as follows.

1) Literature Study

A literature study is a stage to study references related to theories that will be the basis for designing and building this chatbot application.

\section{2) Designing and Building}

The chatbot application that was built consisted of two applications, namely the front-end chatbot application on the web from the PT Feature Technology Innovation and website-based content management system (CMS).

3) Application Creation

After the design and structure of the application are complete, the application creation process will be carried out. The manufacturing process includes designing front-end chatbots and CMS for chatbots. Making an application includes the design of interface designs and additional features needed by the application.

4) Application Testing

Application testing will be done by testing and debugging. The testing will be done with the chatbot application that has been designed and built according to the requirements set. If a bug or error is found, the debugging code will be done to correct the error.

5) Evaluation

At the evaluation stage, statements, and words that cannot be responded to by the chatbot will be examined. From the results of the study, if there are relevant words or statements, the relevant words and statements will be added to the chatbot database. The success rate of applications that have been designed and built will be measured by distributing the TAM questionnaire.

\subsection{Data Collection Technique}

Data regarding information and statements related to chatbot responses will be collected based on information provided by the company. In the testing phase, data were collected using a field study method by providing a link to the website of the chatbot, then asking about the experience of using the chatbot in the form of a questionnaire. The collected questionnaires were then calculated using a five-level Likert Scale and TAM method, in contrast to using System Usability Scale [12].

\subsection{Sample Collection Technique}

The sample collection techniques used in this study is simple random sampling. Each sample chosen is someone who can type and can use a web browser to access the website. Samples were taken randomly for system testing and questionnaire distribution. 


\section{RESULTS AND ANALYSIS}

\subsection{Implementation Results}

Overall, system development is done using the PHP programming language. Frontend acts as a communication medium as well as a means of interaction between users and chatbots. Customer service Fiturebot Chatbot is built with PHP-based website programming. The front end is built by combining Jquery with Program O's Library to read user acceptance patterns so that it can produce responses that are by AIML data. While the admin backend is built using the Program O framework.

The followings are some screenshots of the application. Fig. 1 shows chatbot front end pages. Fig. 2 shows back end login pages.

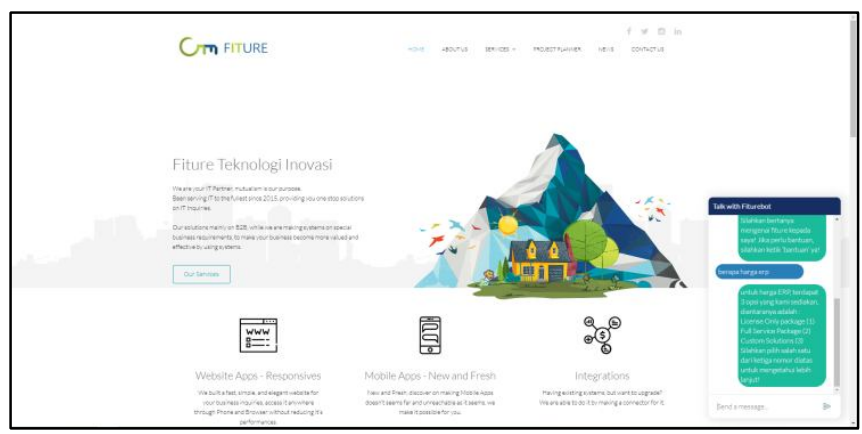

Figure 1: Front End Page

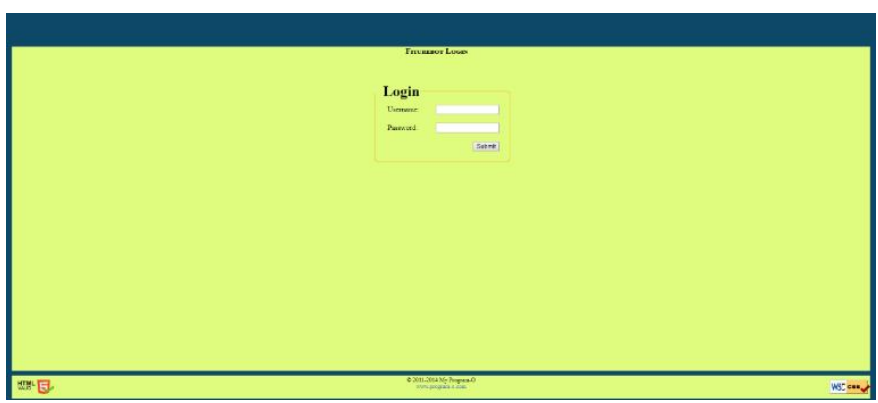

Figure 2: Back End Login Page

Fig. 3 is the home page screen. The following materials are locked until the user finished the current material. Fig. 4 conversation logs and unknown inputs pages.

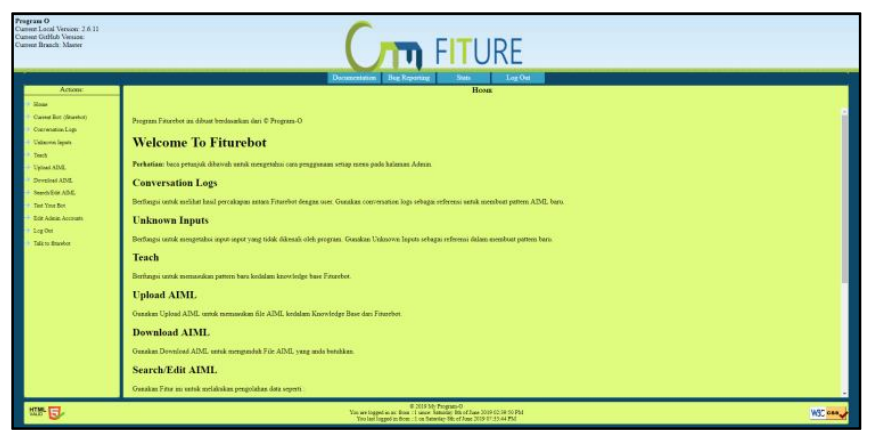

Figure 3: Home Page

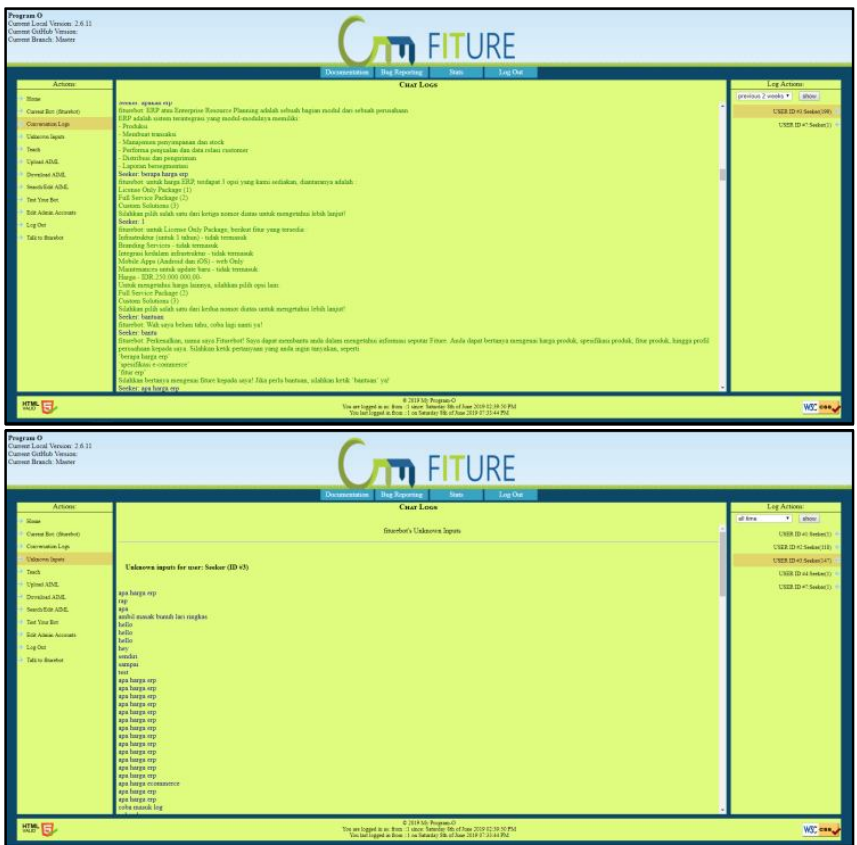

Figure 4: Conversation Logs Page and Unknown Inputs Page

Fig. 5 shows the teach page. Fig. 6 shows upload and download AIML pages.
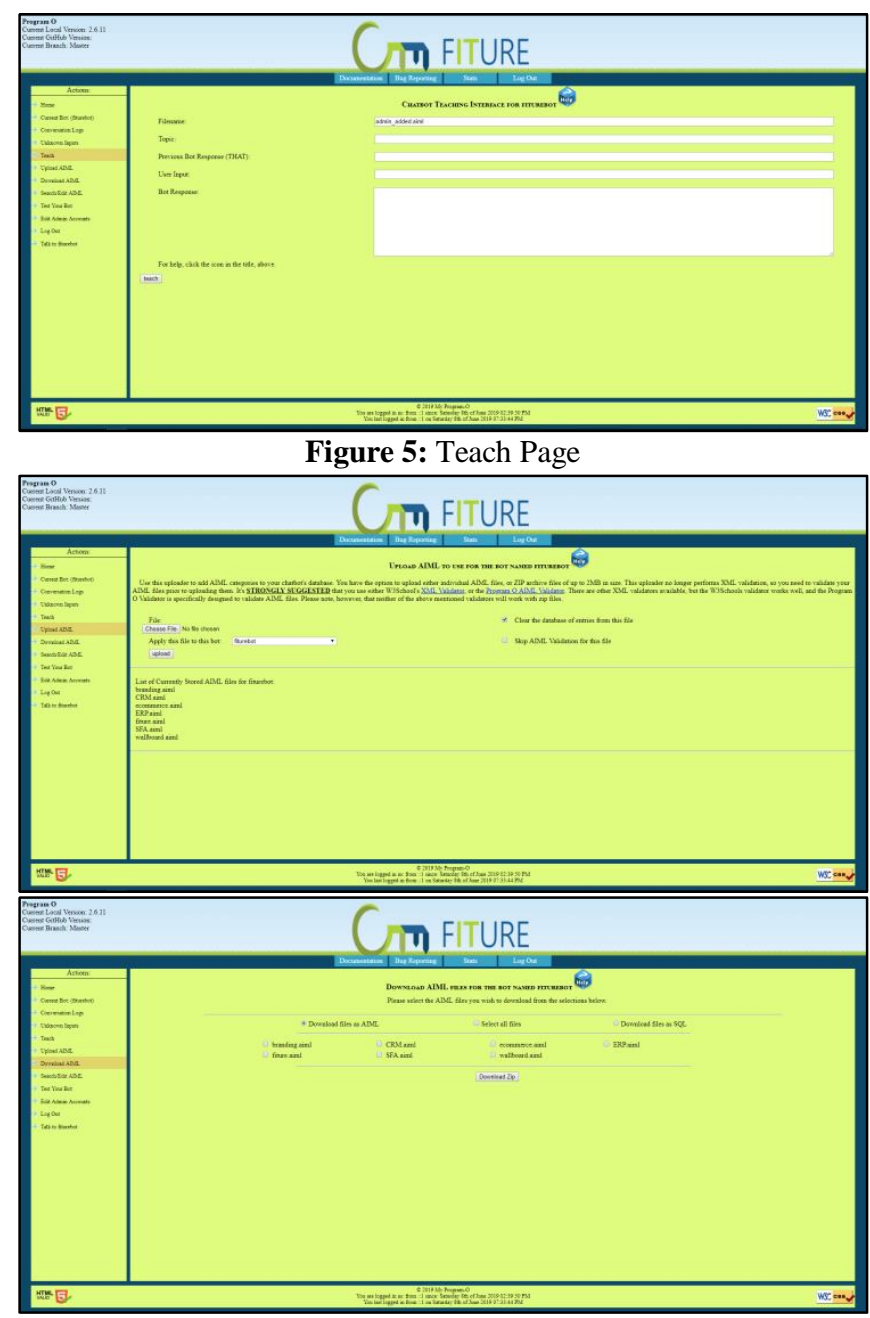

Figure 6: Upload and Download AIML Page 
Fig. 7 shows search/edit AIML page. Fig. 8 shows the edit admin accounts page.

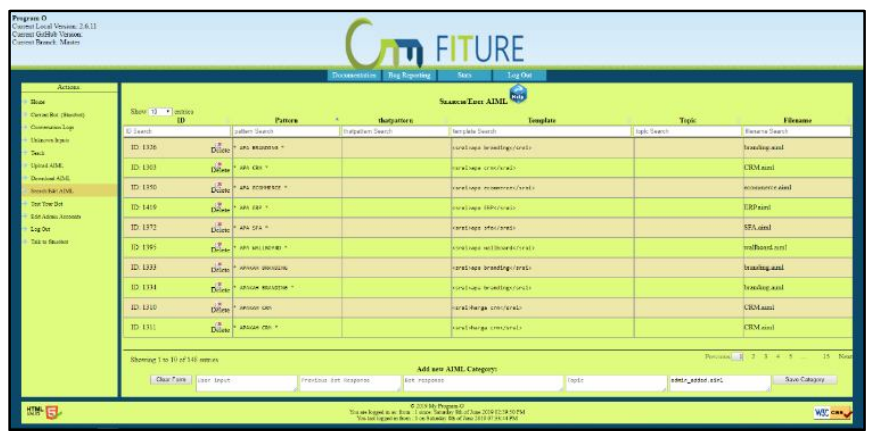

Figure 7: Search/edit AIML Page

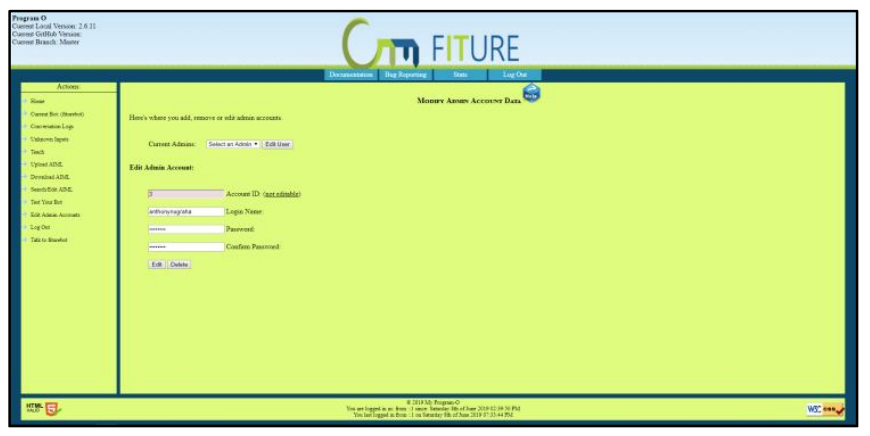

Figure 8: Edit Admin Accounts Page

\subsection{TAM Results}

An evaluation based on TAM to measure the perceived ease of use and perceived usefulness related to the application has been conducted. The participants are 30 people who have accessed the Fiture website and have tested the chatbot. Table 1 shows the results.

Table 1: Evaluation Results

\begin{tabular}{|l|l|}
\hline Factor & Results (\%) \\
\hline Perceived Ease of Use & $83.44 \%$ \\
\hline Perceived Usefulness & $84.78 \%$ \\
\hline
\end{tabular}

From Table 1, $83.44 \%$ of participants agree that the application does not require much effort to use and $84.78 \%$ of participants agree that the application can improve user performance in finding the information that they needed.

\section{CONCLUSION}

In this study, customer service Fiturebot chatbot using the Nazief and Adriani algorithm has been successfully built. It has been implemented on the PT Fiture Teknologi Inovasi website and can respond to the customer questions.

Based on the evaluation results, it is stated that $83.44 \%$ of respondents strongly agree that customer service Fiturebot chatbot is easy to use without requiring much effort to use them and $84.78 \%$ of respondents strongly agree that customer service Fiturebot chatbot can improve user performance in finding the information that they needed. For future research, the chatbot application can be used to collect data from customer as explained by Wang et al. [13] and to prevent customer churn drawback [14].

\section{ACKNOWLEDGEMENT}

The authors would like to say thank you for the support and facilitation given by Universitas Multimedia Nusantara for the research project.

\section{REFERENCES}

1. W. Wardiana. Perkembangan Teknologi Informasi di Indonesia. Universitas Komputer Indonesia, 2002.

2. A. Rastogi, Introduction to chatbots. Available at Newgenapps.com: www.newgenapps.com, 2018.

3. C. Triawati. Metode Pembobotan Statistical Concept Based untuk Klastering dan Kategorisasi Dokumen Berbahasa Indonesia, Statistical Concept Based Weighting Method for Indonesian Language Document Clustering and Categorization. Theses, IT TELKOM Jakarta, 2009.

4. F.D. Davis. Perceived Usefulness, Perceived Ease of Use, and User Acceptance of Information Technology, MIS Quarterly, 1989.

https://doi.org/10.2307/249008

5. S.M. Kasmir. Etika Customer Service. Jakarta, 2002.

6. A. Deshpande, A. Shahane, D. Gadre, M. Deshpande, and P.M. Joshi. A Survey of Various Chatbot Implementation, International Journal of Computer Engineering and Applications, vol.11, 2017.

7. L. Agusta. Perbandingan Algoritma Stemming Porter dengan Algoritma Nazief \& Adriani untuk Stemming Dokumen Teks Bahasa Indonesia, in Proc. Konferensi Nasional Sistem dan Informatika, Bali, 2009, pp.196-201.

8. V. Ferdina, M.B. Kristanda, and S. Hansun. Automated Complaints Classification using Modified Nazief-Adriani Stemming Algorithm and Naive Bayes Classifier, Journal of Theoretical and Applied Information Technology, vol.97, no.5, 2019, pp.1604-1614.

9. D. Domarco and N.M.S. Iswari. Rancang Bangun Aplikasi Chatbot Sebagai Media Pencarian Informasi Anime Menggunakan Regular Expression Pattern Matching, ULTIMATICS, vol.9, no.1, 2017, pp.19-24. https://doi.org/10.31937/ti.v9i1.559

10. R.S. Wallace. The Slashdot Interview: AIML Overview, 2001.

11. F. Hambali, A. Akhirson, and R. Wijayanti. Analisis Technology Acceptance Model (TAM) Terhadap Faktor-Faktor yang Mempengaruhi Penerimaan Nasabah terhadap Layanan Internet Banking (Studi Empiris terhadap Nasabah Bank di Depok), in Proc. PESAT, vol. 4, 2011, pp.E-121 - E-127.

12. E. Sudarmilah and M. Thoyib. Stop Demam Berdarah Dengue (DBD) - Virtual Reality Application for Learning about Dengue Fever, International Journal of 
Anthony Nugraha et al., International Journal of Emerging Trends in Engineering Research, 8(2), February 2020, 350 - 354

Emerging Trends in Engineering Research, vol.7, no.11, 2019, pp.441-448.

https://doi.org/10.30534/ijeter/2019/077112019

13. G. Wang, N. Alamas, and M. Anggraeni. The Use of Internet of Things and Big Data to Improve Customer Data in Insurance Company, International Journal of Emerging Trends in Engineering Research, vol.7, no.12, 2019, pp.756-761.

https://doi.org/10.30534/ijeter/2019/047122019

14. P. Hooda and P. Mittal. An Exposition of Data Mining Techniques for Customer Churn in Telecom Sector, International Journal of Emerging Trends in Engineering Research, vol.7, no.11, 2019, pp.506-511.

https://doi.org/10.30534/ijeter/2019/177112019 